\title{
Religion and Politics in the Developing World: Explosive Interactions(cf. Arch. supra. François Mabille)
}

Ashgate, North Carolina Central University, 2002, 159 p. (index) (cf. Arch. supra, pp. 27-30)

\section{OpenEdition}

\section{Journals}

Édition électronique

URL : http://journals.openedition.org/assr/1443

DOI : 10.4000/assr.1443

ISSN : $1777-5825$

Éditeur

Éditions de l'EHESS

\section{Édition imprimée}

Date de publication : 1 avril 2003

ISBN : 2-222-96732-5

ISSN : 0335-5985

Référence électronique

"Religion and Politics in the Developing World: Explosive Interactions(cf. Arch. supra. François Mabille) ", Archives de sciences sociales des religions [En ligne], 122 | avril - juin 2003, document 122.86, mis en ligne le 10 novembre 2005, consulté le 25 avril 2019. URL : http://journals.openedition.org/ assr/1443; DOI : 10.4000/assr.1443

Ce document a été généré automatiquement le 25 avril 2019

Archives de sciences sociales des religions 


\section{Religion and Politics in the} Developing World: Explosive Interactions(cf. Arch. supra. François Mabille)

Ashgate, North Carolina Central University, 2002, 159 p. (index) (cf. Arch. supra, pp. 27-30) 